\title{
EFFECT OF SITE AND COMPETITION ON DIAMETER GROWTH OF Araucaria angustifolia
}

\author{
Mário Dobner Jr. ${ }^{1 *}$ Crysttian Arantes Paixão ${ }^{2}$ Emanuel Arnoni Costa ${ }^{3}$ Cesar Augusto Guimarães Finger ${ }^{4}$ \\ ${ }^{1}$ Universidade Federal de Santa Catarina, Curitibanos, SC, mario.dobner@ufsc.br, *autor para correspondência \\ ${ }^{2}$ Universidade Federal de Santa Catarina, Curitibanos, SC, crysttian.arantes.paixao@ufsc.br \\ ${ }^{3}$ Universidade Federal de Santa Maria, Santa Maria, RS, emanuelarnonicost@gmail.com \\ ${ }^{4}$ Universidade Federal de Santa Maria, Santa Maria, RS, cesarfinger.ufsm@gmail.com
}

Received for publication: 27/02/2018 - Accepted for publication: 05/04/2019

\begin{abstract}
Resumo
Efeito do sítio e da competição no crescimento em diâmetro de Araucaria angustifolia. Apesar do histórico de interesse pelo uso da madeira de Araucaria angustifolia, a espécie ainda é pouco conhecida no que diz respeito aos fatores que afetam seu crescimento. Um maior entendimento neste sentido pode contribuir para o desenvolvimento de sistemas de manejo adequados, aumentando, assim, a produtividade de plantios e, consequentemente, o interesse pelo uso comercial da espécie. O presente estudo foi baseado em povoamentos monoespecíficos estabelecidos em diferentes condições de sítio (Índices de Sítio entre 18-24), onde os indivíduos $(\mathrm{n}=654)$ foram expostos a diferentes níveis de competição. Com o auxílio de técnicas de regressão múltipla foram determinados os fatores que afetaram de forma significativa o crescimento acumulado em diâmetro das árvores passados 20 anos da intervenção. Para o conjunto formado por 'todas' as árvores, $77 \%$ da variação do crescimento pôde ser explicada por três fatores: sítio, proporção do diâmetro à altura do peito (dap) da árvore objeto de análise em relação ao dap médio do povoamento antes da realização dos desbastes $\left(\mathrm{C}_{\text {dap_antes }}\right)$ e status de dominância em relação às árvores vizinhas $\left(\mathrm{C}_{\text {todas }}\right)$. A significância do grau de competição das árvores antes do desbaste $\left(\mathrm{C}_{\text {dap_antes }}\right)$ indica que desbastes tardios possuem efeitos limitados no crescimento das árvores. Conclui-se que os indivíduos são beneficiados por possuir uma posição dominante em relação às árvores vizinhas, atingindo diâmetros 50\% maiores ao final do ciclo de produção. Desbastes que favorecem árvores selecionadas pela remoção de competidoras diretas parecem ser uma estratégia interessante de manejo para a espécie.

Palavras-chave: Pinheiro-do-paraná; Manejo Florestal; Silvicultura; Produção de Madeira.
\end{abstract}

\begin{abstract}
Although the historical interest in using the wood of Araucaria angustifolia, it is still little known concerning the factors that affect the growth. A broader understanding in this context might contribute to the development of appropriate management systems, thus increasing the productivity of plantations and, consequently, the interest in commercially using this species. The present study was based on monospecific populations established in different site conditions (Site Indices between 18-24) where individuals $(n=654)$ were submitted to different competition levels. With the aid of multiple regression techniques, the factors that significantly affected the accumulated growth in diameter of the trees after 20 years of intervention were determined. For the set formed by all trees, $77 \%$ of the growth variation can be explained by three factors: site, the proportion of tree diameter at breast height $(d b h)$ of the object tree for analysis in relation to the average dbh of the population before performing the thinning $\left(\mathrm{C}_{d b h}\right.$ before $)$ and dominance status in relation to the neighboring trees $\left(\mathrm{C}_{\text {all }}\right)$. The significance of the competition level before the thinning shows that late thinnings have limited effects on tree growth. It is concluded that individuals are benefited for having a dominant position in relation to the neighboring trees, reaching diameters $50 \%$ larger at the end of the production cycle. Thinnings that favour selected trees by removing direct competitors seem to be an interesting management strategy for the species.
\end{abstract}

Keywords: Paraná-pine; Forest Management; Silviculture; Timber Production.

\section{INTRODUCTION}

Araucaria angustifolia (Bert.) O. Kuntze, known as Paraná pine, is typical of Mixed Ombrophilous Forest, or Forest with Araucaria. The species was responsible for an important economic cycle during the XX century, when its timber was intensively exploited. This is the reason for today being in the list of critically endangered species (THOMAS, 2013), with severe restrictions of use.

Although the history proves the interest for using the timber of A. angustifolia, and the recognized productive potential of the species (CARVALHO, 2003; NUTTO et al., 2005; ABRAF, 2010; FIGUEIREDO F ${ }^{\circ}$ et al., 2014), the factors that influence its growth are still little known (SANTOS et al., 2010). Due to the unknown

FLORESTA, Curitiba, PR, v. 49, n. 4, p. 717 - 724, out/dez 2019.

Dobner Jr., M. et.al.

ISSN eletrônico 1982-4688

DOI: $10.5380 /$ rf.v49 i4.58161 
of ecology of the species mistakes were committed in establishing and managing plantations of A. angustifolia (SEITZ, 1986; NUTTO et al., 2005), which together with bureaucracy for using these plantations, resulted in commercial desinterest.

The few commercial plantations of A. angustifolia currently existent ( 10,000 ha, ABRAF, 2010; IBÁ, 2017) are not managed in their great majority, providing a view that does not correspond to the real potential of growth and economic viability of the species silviculture (SANTOS et al., 2010).

A better understanding of factors that affect the growth and production can contribute for the development of proper management systems for A. Angustifolia, and thus, increase the interest for using it in commercial plantations (SANTOS et al., 2010), which besides increasing the supply of high quality timber, could contribute with preservation of the species and biodiversity of this physiognomies (FONSECA et al., 2009).

Koehler et al. (2010) pointed out that accumulated experience shows A. angustifolia cultivation has to be preceded by a strict selection of sites once in inadequate areas the growth can be unsatisfactory.

Among the available strategies of management, thinnings are an important tool for the forester because they permit manipulating stand density and thus, productive space available for remaining trees. However, individuals in a thinned stand do not have the same conditions of growth, mainly related to competition status of each individual in relation with the neighboring ones, and to other trees in the stand. Likewise, the individual analysis of the trees, considering different indices of competition is an interesting approach that allows a better understanding of effects of competition or its absence on tree growth. Indices of competition can be dependent, independent or semi-independent of distance. The two first are self-explanatory ones. The third, semi-independent, is characterized by using the independent indices, however, considering only the neighboring trees to the object tree of the analysis, resulting in indices that characterize the local of the object tree without using distance among individuals.

As hypothesis, the conditions of site and competition among individuals influence the growth of $A$. angustifolia. Thus, this study was realized in order to better understand and quantify the effect of these two variables on the diameter growth of A. angustifolia.

\section{MATERIAL AND METHODS}

The study was developed in monospecific plantations in different conditions of site quality, where individuals of A. angustifolia had the environment changed by thinnings. Some stands were not thinned and helped evaluate the performance of trees at high levels of competition.

\section{Study Area}

The populations analyzed were located in the municipalities of Campo Belo do Sul and Capão Alto, Southern plateau of Santa Catarina, $\sim 900 \mathrm{~m}$ altitude. According to the classification of Köppen, the climate is the $\mathrm{Cfb}$ type, mesothermal, wet subtropical, with cool summers, without dry seasons and with severe frosts. The average annual precipitation is from 1.300 to $2.400 \mathrm{~mm}$.

\section{Growth conditions}

In the winter of 1996, different conditions for tree growth were established due to thinning in three distinct locals. Three treatments were regarded, characterized by maintenance of all trees (unthinned), removal of half the trees with thinning 'from below', and removal of the main competitor from 200 dominant trees previously selected due to dominance, quality and distribution, thus characterizing a thinning 'from above', also known as crown thinning.

Detailed information about the stands studied before and after thinning are presented in Table 1. It is evident that different conditions for growth of trees were established.

The different growth conditions were applied in plots with $\sim 1,500 \mathrm{~m}^{2}\left(\sim 800 \mathrm{~m}^{2}\right.$ used for measurements), with at least 100 individuals per plot before and 60 after interventions in each of them.

\section{Data collection}

The diameters at breast height $(d b h, 1.3 \mathrm{~m})$ of all individuals were obtained with measuring tape at the moment thinnings were carried out (1996), and 20 years after intervention. In the last data collection (2016), the dominant heights were also measured for classifying the site quality of sample units, as shown in Table 1.

\section{Data Analysis}

The trees of A. angustifolia were submitted to several growth conditions, characterized by removal of trees, site index, basal area before and after interventions. This environmental diversity at which the trees were 
submitted, permitted realization of multiple regression analysis for determining the factors that affected consistent and significantly the accumulated growth in diameter of trees.

Table 1. Age of the stand when thinning was carried out, site index (SI) after Schneider et al. (1992), number of trees per hectare $(N)$, basal area $(G)$, quadratic mean diameter $\left(d_{g}\right)$ per local and treatment in 1996 , before and after thinning.

Tabela 1. Idade do povoamento no momento do desbaste, índice de sítio $(I S)$ segundo classificação proposta por Schneider et al. (1992), número de árvores por hectare $(N)$, área basal $(G)$ e diâmetro quadrático médio $\left(d_{g}\right)$ por local e condição de crescimento, antes e depois dos desbastes.

\begin{tabular}{|c|c|c|c|c|c|c|c|c|c|}
\hline \multirow{2}{*}{$\begin{array}{c}\text { Local } \\
\text { (year of planting) }\end{array}$} & \multirow{2}{*}{$\begin{array}{c}\text { Age at } \\
\text { intervention } \\
\text { (years) }\end{array}$} & \multirow{2}{*}{$\begin{array}{l}\text { Growth } \\
\text { Condition }\end{array}$} & \multirow[t]{2}{*}{$S I^{1}$} & \multicolumn{2}{|c|}{$\begin{array}{c}N \\
\left(\text { tree } \mathrm{ha}^{-1}\right)\end{array}$} & \multicolumn{2}{|c|}{$\begin{array}{c}\boldsymbol{G} \\
\left(\mathrm{m}^{2} \mathrm{ha}^{-1}\right)\end{array}$} & \multicolumn{2}{|c|}{$\begin{array}{c}\boldsymbol{d}_{g} \\
(\mathrm{~cm})\end{array}$} \\
\hline & & & & before & after & before & after & before & after \\
\hline \multirow{3}{*}{$\begin{array}{c}1 \\
(1979)\end{array}$} & \multirow{3}{*}{17} & unthinned & 22 & 1,700 & 1,700 & 33.6 & 33.6 & 15.7 & 15.7 \\
\hline & & from below & 20 & 1,300 & 750 & 22.8 & 19.1 & 14.9 & 17.9 \\
\hline & & from above & 22 & 1,450 & 1,250 & 36.3 & 30.3 & 17.9 & 17.6 \\
\hline \multirow{3}{*}{$\begin{array}{c}2 \\
(1981)\end{array}$} & \multirow{3}{*}{15} & unthinned & 24 & 1,800 & 1,800 & 40.6 & 40.6 & 16.9 & 16.9 \\
\hline & & from below & 22 & 1,500 & 850 & 47.3 & 35.3 & 20.1 & 23.0 \\
\hline & & from above & 22 & 1,800 & 1,600 & 35.4 & 30.6 & 15.9 & 15.6 \\
\hline \multirow{3}{*}{$\begin{array}{c}3 \\
(1985)\end{array}$} & \multirow{3}{*}{11} & unthinned & 18 & 2,300 & 2,300 & 25.5 & 25.5 & 11.9 & 11.9 \\
\hline & & from below & 18 & 1,800 & 1,000 & 25.4 & 19.3 & 13.4 & 15.8 \\
\hline & & from above & 18 & 2,250 & 2,050 & 27.0 & 24.4 & 12.4 & 12.3 \\
\hline
\end{tabular}

${ }^{1}$ Site index, values correspond to average dominant height at reference age 40.

The response variable analyzed was $d b h$ of trees at the end of the analysis period, 31-37 years, 20 years after thinning, depending on the local.

The following factors with possible influence on tree growth were evaluated:

- $\quad$ Site index $(S I)$, varying from 18 to 24 , value corresponding to average dominant height at age reference of 40 years (SCHNEIDER et al., 1992).

- Indices of competition independent from distance, relating $d b h$ of object tree to the analysis with average $d b h$ of respective growth condition before and after thinnings $\left(\mathrm{C}_{d b h_{-} \text {before }}\right.$ and $\left.\mathrm{C}_{d b h_{-} \text {after }}\right)$. Values between 0.046 and 3.302 were analyzed.

$$
C_{d b h_{-} \text {before }}=\frac{d b h_{i}}{\overline{d b h}_{\text {before }}} \quad \quad C_{\text {dbh_after }}=\frac{d b h_{i}}{\overline{d b h} \_ \text {ffter }_{\text {f }}}
$$

- Indices of competition independent from distance, relating transversal area $(g)$ of object tree for analysis with average transversal area of respective growth condition, before and after thinning $\left(\mathrm{C}_{g_{-} \text {before }}\right.$ and $\left.\mathrm{C}_{g_{-} \text {after }}\right)$. Values between 0.002 and 8.406 were evaluated.

$$
C_{g_{-} \text {before }}=\frac{g_{i}}{\bar{g}_{-} \text {before }} \quad \quad C_{g_{-} \text {after }}=\frac{g_{i}}{\bar{g}_{\_} \text {after }}
$$

- Index of competition semi-independent from distance, relating transversal area of analysed individual with the sum of transversal areas of neighboring trees $(j)$, right after performing thinning $\left(\mathrm{C}_{\text {all }}\right)$, and with maximum of 8 trees - all trees that surrounded the analysed one. The higher the value, the lower the competition level existent among them. The trees analyzed showed values between 0.006 and 1.961 .

$$
C_{\text {all }}=\frac{g_{i}}{\sum_{j=1}^{n} g_{j}}
$$

- Index of competition semi-independent from distance, relating transversal area of individual object for analysis only with the transversal area of the largest neighboring tree right after thinning $\left(\mathrm{C}_{\text {largest }}\right)$. Values higher than 1 show the tree dominated the local, while values lower than 1 show suppression of the object tree. Values between 0.023 and 2.277 were part of the database.

$$
\mathrm{C}_{\text {largest }}=\frac{\mathrm{g}_{\mathrm{i}}}{g_{\text {larger }}}
$$

Where, $d b h_{i}$ : diameter at breast height of object tree for analysis; $\overline{d b h}$ : average $d b h$ of respective growth condition to which the tree $i$ was submitted, before and after thinning; $g_{i}$ : transversal area of object tree for analysis; $\bar{g}$ : average transversal area of respective growth condition to which the tree $i$ was submitted, before and after thinning; $g_{j}$ : transversal area of neighboring trees, from 1 to 8 individuals per object tree; $g_{\text {largest }}$ : the largest transversal area among the 8 possible neighboring trees.

The factors previously described were correlated (Pearson) with variable response $(d b h)$.

With the aid of multiple regression techniques, the factors that best composed a prediction model for $d b h$ were determined, using the lowest possible number of factors, in a biologically coherent way, aiming to maximize

FLORESTA, Curitiba, PR, v. 49, n. 4, p. 717 - 724, out/dez 2019.

Dobner Jr., M. et.al.

ISSN eletrônico 1982-4688

DOI: $10.5380 /$ rf.v49 i4.58161 
the coefficient of determination $\left(\mathrm{R}^{2}\right)$, and minimize the standard error of estimate $\left(\mathrm{S}_{\mathrm{yx}}\right)$. Only factors with significant parameters were kept in the models. After adjusting the model, it was only accepted after confirmation of assumptions of multiple linear regression: normality, homocedasticity and independence of residues; factors with multicollinearity were not concomitantly used in the adjusted models - factors with variation inflation factor (VIF) higher than 4 were not accepted. The factor with the greatest influence in $\mathrm{R}^{2}$ of the model was kept over the other.

The modeling considered site indices as categorical variables. Preliminar analyses showed there were no significant differences of growth in $d b h$ of the trees in the sites ' 20 ' and ' 22 ', thus these two classes of site were analyzed together, in a group called ' 21 '.

The test of factors and adjustment of the models were carried out using the language R (R CORE TEAM, 2016), and two databases were considered: all trees $(n=693)$ and the 200 with the largest $d b h$ ha $^{-1}$ at the end of analysis period $(\mathrm{n}=122)$; thus, characterizing different dominance levels.

\section{RESULTS}

The populations evaluated in this study showed mean annual increment (MAI) in commercial volume $\left(\varnothing>8 \mathrm{~cm}\right.$ ) between 8.2 and $23.3 \mathrm{~m}^{3} \mathrm{ha}^{-1}$ year $^{-1}$.

Considering the importance of site quality, this variable was considered categorical, reason for which linear coefficients are presented $\left(\beta_{0}\right)$ distinct for the same database, one per site index (Table 2).

Table 2. Multiple regression analysis of the factors that influence the diameter at breast height $(d b h)$ of $A$. angustifolia, for all the trees in the stand and for the 200 trees $^{-1} \mathrm{w}^{-}$with the largest $d b h$ at the end of the analysis period (31-37 years). The estimated parameters are presented $(\hat{\beta})$ for the models, considering the reduction in number of non-significant factors, the respective values of probability $(p)$, Pearson's correlation in relation to the variable response $\left(p<0.01=* *, p<0.05=^{*}\right)$, partial contribution of the factor to the coefficient of determination $\left(\mathrm{R}^{2}\right.$ partial) and the variation inflation factor (VIF) among present factors at the final model. The coefficient of determination $\left(\mathrm{R}^{2}\right)$, the standard error of estimation $\left(\mathrm{S}_{\mathrm{yx}}\right)$ in percentage and significance considering the model as a whole, are also informed.

Tabela 2. Análise de regressão múltipla dos fatores que influenciam o diâmetro à altura do peito (dap) acumulado de $A$. angustifolia, para todas as árvores do povoamento e para as 200 árvores ha ${ }^{-1}$ de maior dap ao final do período de análise (31-37 anos). São apresentados os parâmetros estimados $(\hat{\beta})$ dos modelos já considerando a redução do número de fatores não significativos, seus respectivos valores de probabilidade $(p)$, correlação de Pearson em relação à variável resposta $(p<0,01=* *, p<0,05=*)$, contribuição parcial do fator no coeficiente de determinação $\left(\mathrm{R}_{\text {parcial }}^{2}\right)$ e o VIF entre os fatores presentes no modelo final. $\mathrm{O}$ coeficiente de determinação $\left(\mathrm{R}^{2}\right)$, o erro padrão da estimativa $\left(\mathrm{S}_{\mathrm{yx}}\right)$ em porcentagem e a significância considerando o modelo como um todo, são também informados.

\begin{tabular}{|c|c|c|c|c|c|c|c|c|c|c|}
\hline \multirow[b]{2}{*}{ Factors } & \multicolumn{5}{|c|}{ All } & \multicolumn{5}{|c|}{200} \\
\hline & $\hat{\beta}$ & $p$ & Pearson & $\mathrm{R}_{\text {partial }}^{2}$ & VIF & $\hat{\beta}$ & $p$ & Pearson & $\mathrm{R}_{\text {partial }}^{2}$ & VIF \\
\hline$S I 18-\beta_{0}$ & 5.779 & $<0.01$ & & 0.118 & 1.1 & 22.818 & $<0.01$ & & 0.554 & 1.0 \\
\hline$S I 21-\beta_{0}$ & 9.314 & $<0.01$ & & & & 29.731 & $<0.01$ & & & \\
\hline SI $24-\beta_{0}$ & 11.357 & $<0.01$ & & & & 34.297 & $<0.01$ & & & \\
\hline $\mathrm{C}_{d b h \_ \text {before }}$ & 8.618 & $<0.01$ & $0.80 * *$ & 0.603 & 1.6 & 1.867 & $<0.01$ & $0.32 * *$ & 0.053 & 1.1 \\
\hline $\mathrm{C}_{d b h_{-} \text {after }}$ & & & $0.71 * *$ & & & & & $0.21 *$ & & \\
\hline $\mathrm{C}_{g_{-} \text {before }}$ & & & $0.71 * *$ & & & & & $0.28 * *$ & & \\
\hline $\mathrm{C}_{g_{-} \text {after }}$ & & & $0.64 * *$ & & & & & $0.20 *$ & & \\
\hline $\mathrm{C}_{\text {all }}$ & 11.406 & $<0.01$ & $0.72 * *$ & 0.051 & 1.7 & 3.324 & $<0.01$ & $0.39 * *$ & 0.039 & 1.1 \\
\hline $\mathrm{C}_{\text {largest }}$ & & & $0.77 * *$ & & & & & $0.22 *$ & & \\
\hline $\mathrm{R}^{2}$ & \multicolumn{2}{|c|}{0.772} & \multicolumn{8}{|c|}{0.650} \\
\hline $\mathrm{S}_{\mathrm{yx}}$ & \multicolumn{2}{|c|}{$18.7 \%$} & & & & \multicolumn{2}{|c|}{$10.3 \%$} & & & \\
\hline$p$ & \multicolumn{2}{|c|}{$<0.01$} & & & & \multicolumn{2}{|c|}{$<0.01$} & & & \\
\hline
\end{tabular}

It is observed in Table 2 that the regression models fitted for the different databases was possible. Although the model adjusted for 'all' trees presented a higher coefficient of determination, the standard error of estimate was also higher for this database when compared to the model adjusted for the ' 200 ' dominant trees ha ${ }^{-1}$. 
For the data set composed of 'all' trees, a substantial portion (77\%) of growth variation can be explained by the three factors analyzed and selected: site, $d b h$ proportion of object tree with the average $d b h$ of stand before thinning $\left(\mathrm{C}_{d b h \_ \text {before }}\right)$ and status of dominance in relation to neighboring trees $\left(\mathrm{C}_{\text {all }}\right)\left(\mathrm{R}^{2}=0.772\right)$.

In general, the indices of competition independent from distance, $\left(\mathrm{C}_{d b h}\right.$ and $\left.\mathrm{C}_{g}\right)$ showed higher correlations with $d b h$ 'before' thinning. Therefore, it is inferred that the level of competition reached by individuals has important effect on the future growth in $d b h$, even though the growth environment (competition level) is later changed by thinnings.

In relation to indices of competition semi-independent from distance $\left(\mathrm{C}_{\text {all }}\right.$ and $\left.\mathrm{C}_{\text {largest }}\right)$, it was determined that the indice regarding eight neighboring trees that surrounded the object tree was more efficent in prediciting final $d b h$ of the trees than regarding only the largest one $\left(\mathrm{C}_{\text {largest }}\right)$. However, it is observed that $\mathrm{C}_{\text {largest }}$ was also strongly correlated with the $d b h$ of the trees.

It was verified that all indices of competition were less correlated with final $d b h$ of the trees when the dominance of individuals considered was higher ('200'). This behavior was coherent and expected. Whereas for all trees the indice of competition $\mathrm{C}_{d b h}$ before represented $60 \%$ of the capacity for explaining $d b h$ of the trees at the final study period $\left(\mathrm{R}_{\text {partial }}^{2}=0.603\right)$, this one was of only $5.3 \%\left(\mathrm{R}^{2}\right.$ partial $\left.=0.053\right)$ for the ' 200 ' dominant trees ha' ${ }^{-1}$; at the same time the importance of the site increased. In other words, once in favorable position in relation to the neighboring trees (dominant individuals), the factor that defines the growth in $d b h$ of the trees is predominantly the site.

Fitted models are presented below:

$$
\begin{aligned}
& d b h_{\text {all }}=5.779 \times I(S I 18)+9.314 \times I(S I 21)+11.357 \times I(S I 24)+8.618 \times C_{d b h_{\text {before }}}+11.406 \times C_{\text {all }} \\
& d_{200}=22.818 \times I(S I 18)+29.731 \times I(S I 21)+34.297 \times I(S I 24)+1.867 \times C_{d b h_{\text {before }}}+3.324 \times C_{\text {all }}
\end{aligned}
$$

where ' $I$ ' is an indicator function that worth 1 when the site is analyzed; otherwise, 0 .

Figure 1 presents the application of the fitted model for 'all' trees of the stand, individually plotted due to the two factors selected in order of importance: $\mathrm{C}_{d b h \_ \text {before }}$ and $\mathrm{C}_{\text {all }}$.
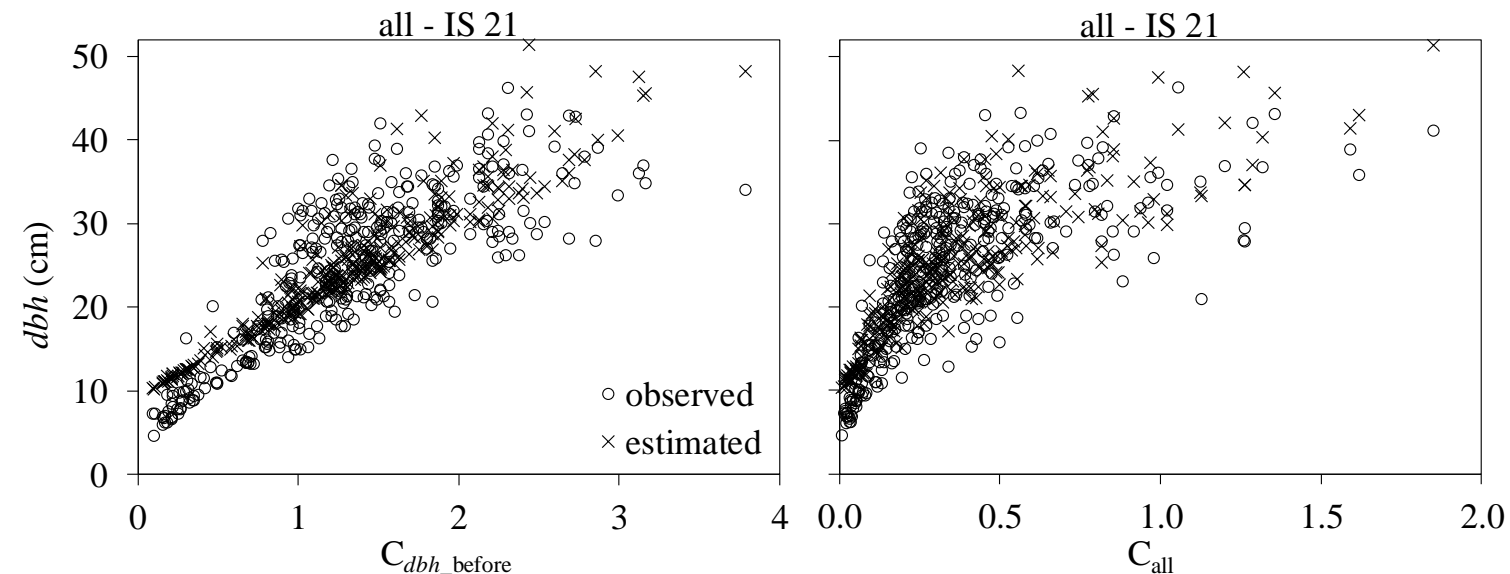

Figure 1. Diameter at breast height $(d b h)$ observed and estimated from the fitted model for all trees in the stant (Table 2) at an intermediate site (IS 21), plotted according to the selected factors: ' $\mathrm{C}_{d b h_{-} \text {before' }}$ and ' $\mathrm{C}_{\text {all }}$ '.

Figura 1. Diâmetro à altura do peito (dap) observado e estimado a partir do modelo ajustado para todas as árvores do povoamento (Tabela 2) em um sítio intermediário (IS 21), plotados em função dos fatores selecionados: 'C $\mathrm{C}_{\text {dap_antes' }} \mathrm{e}$ ' $\mathrm{C}_{\text {todas }}$ '.

It is observed in Figure 1, as detected in the regression analyses previously described, a strong positive linear relation between $d b h$ at the end of the study period and the relation between the $d b h$ of object tree and mean stand $d b h$ before thinning $\left(\mathrm{C}_{d b h}\right.$ before $)$. Similarly, the lower the relation between transversal area of object tree and the sum of transversal areas of the eight neighboring trees $\left(\mathrm{C}_{\mathrm{all}}\right)$ the lower the accumulated diameter at the end of the study period. In other words, the higher the competition to which the object tree was submitted, the smaller the diameter at the end of the studied period. The most abrupt variation of this relation is observed from values 0 to 0.5 , segment of high competition.

The interpretation of the index of competition ' $\mathrm{C}_{\text {all }}$ ' has to be careful, once the denominator is composed by the sum of transversal areas of the eight neighboring trees. A value of $\mathrm{C}_{\text {all }}=0.5$ means, for example, a tree with

FLORESTA, Curitiba, PR, v. 49, n. 4, p. 717 - 724, out/dez 2019.

Dobner Jr., M. et.al.

ISSN eletrônico 1982-4688 
$d b h$ of $20 \mathrm{~cm}$ with two neighboring trees with the same $d b h$, or with eight neighboring trees with $d b h$ of $10 \mathrm{~cm}$. In the second option, the tree is the dominant of the group with better condition for developing and becoming even more dominant in relation to the others. Differently from the first scenario, where the competition for resources is higher. As the same value of $\mathrm{C}_{\text {all }}$ can represent different levels of competition with very distinct practical implications, $d b h$ accumulated is also presented due to the relation of transversal area of object tree only with the largest one among the eight immediate neighboring trees $\left(\mathrm{C}_{\text {largest }}\right)$.

The criterion for classifying a tree as dominant when having transversal area larger than the neighboring tree $\left(\mathrm{C}_{\text {largest }}>1\right)$, although it has not been selected for taking part of the regression models, it had high correlation, and is an interesting indicator for the praxis, which reveals in a more simple and direct way the influence of dominance position of the tree in relation to the neighboring ones (Figure 2).

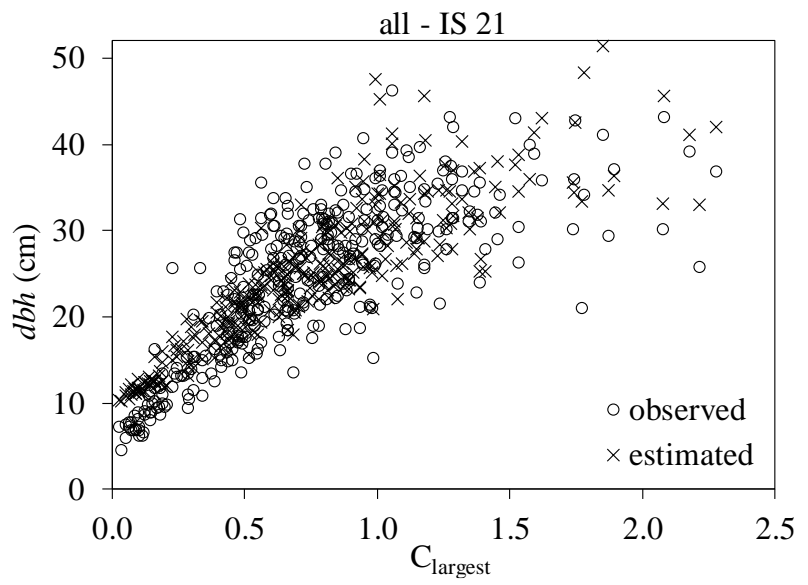

Figure 2. Diameter at breast height $(d b h)$ observed and estimated from the fitted model for all trees at an intermediate site (Table 2, IS 21), plotted according to the distance semi-independent index ' $\mathrm{C}_{\text {largest }}$ '.

Figura 2. Diâmetro à altura do peito (dap) observado e estimado a partir do modelo ajustado para todas as árvores e sítio intermediário (Tabela 2, IS 21), plotados em função do índice semi-independente da distância ' $\mathrm{C}_{\text {maior' }}$ '.

It is more clearly observed in Figure 2 than in Figure 1 that trees in unfavorable dominance condition $\left(\mathrm{C}_{\text {largest }}<1\right)$ have the accumulated diameter strongly and negatively affected. For the group with all trees, the higher the competition of the neighboring trees, $C_{\text {largest }}$ near 0 , the lower the diameter at the end of evaluated period $(\sim 10$ $\mathrm{cm})$. Values close to 0.5 resulted accumulated $d b h$ twice as much as the first one $(\sim 20 \mathrm{~cm})$, while the dominant trees $\left(\mathrm{C}_{\text {largest }}>1\right)$, despite high data variability, resulted trees with $d b h \sim 30 \mathrm{~cm}$.

Grouping the trees in dominated $\left(\mathrm{C}_{\text {largest }}<1\right)$, and dominant $\left(\mathrm{C}_{\text {largest }}>1\right)$, it is verified that the average accumulated $d b h$ at the end of analysis period was of $\sim 20$ and $\sim 30 \mathrm{~cm}$, respectively, a difference of $50 \%$ between the groups.

\section{DISCUSSION}

The mean annual increment (MAI) in volume observed in different studied populations is coherent with those related by Carvalho (2003): 1 to $26 \mathrm{~m}^{3} \mathrm{ha}^{-1}$ year $^{-1}$; and Nutto et al. (2005): 10 to $25 \mathrm{~m}^{3} \mathrm{ha}^{-1}$ year $^{-1}$.

The variation of MAI observed in this study is strongly related to the site index for the sampling unit with indices varying between 18 and $24 \mathrm{~m}$ (reference age 40 years), according to classification proposed by Schneider et al. (1992), shown in Table 1.

It is known that $A$. angustifolia is a species demanding in soil (CARVALHO, 2003; KOEHLER et al. 2010). Previous studies indicate that excellent sites are those where the previous vegetation was forest with soil of high base saturation (high content of interchangeable calcium and magnesium), and thick horizons ' $A$ ', characterized by the relative high organic matter content and biological activity.

The local ' 3 ' evaluated in this study (Table 1), completely characterized as site 18, was consisted of native field and used as natural pasture during the decades that preceded the planting of A. angustifolia. The area was prepared for agricultural cultivation only a year before establishing the population, having been reforested shortly. Locals ' 1 ' and ' 2 ' had native forest, which after timber exploration and burning of residues, were immediately reforested. 
Indices of competition relatively simple were used. Even so, it is possible to assure that were able to explain a substantial portion of data variation. This result is possibly due to the structure simplicity of the populations analyzed, when compared with native forests with higher complexity, and whose modeling of competition effects demand indices equally more complex (CUNHA; FINGER, 2013; CASTRO et al., 2014).

Trees submitted to a long competition period have the construction of the crown affected and need longer time after thinnings for responding to favoring by increase of available space. This lower capacity of response is the result of the same process observed in natural forests related by Seitz (1986) and assumed by Nutto et al. (2005): adult and suppressed individuals would not be able to respond satisfactorily to opening space.

Previous studies (SEITZ, 1986; NUTTO et al. 2005) show a strong relation between $d b h$ and crown diameter of $A$. angustifolia. Trees with $40 \mathrm{~cm}$ of $d b h$ need crowns with $6-10 \mathrm{~m}$ of diameter. For a crown diameter of $8 \mathrm{~m}$, there is an area of $\sim 50 \mathrm{~m}^{2}$, corresponding to a density of $\sim 200$ trees ha- ${ }^{-1}$. Therefore, it is concluded that other interventions would have been necessary for the trees evaluated in this study had shown all the growth potential. The population with lower density in the moment of the present analysis showed $\sim 700$ trees ha-1 $^{-1}$ although several individuals presented $d b h$ 's larger than $30 \mathrm{~cm}$, showing a high level of competition.

It was also verified that the model adjusted for all the trees was less efficient for individuals with $d b h<10$ $\mathrm{cm}$, showing a slight tendency of superestimating the values (Figure 1). This behavior is due to the fact that small size trees do not respond in a consistent way to the increase of available space (SEITZ, 1986; NUTTO et al., 2005). Moreover, according to Peltoniemi and Mäkipää (2011), studying the competition effect in mortality of Picea abies (L.) Karst, there are different answers depending on the size $(d b h)$ of the object tree for analysis and the respective competitors: small trees do not affect the tall ones, and besides, small trees are relatively less affected by competition with big-sized individuals. Both difficult behaviors to be captured by analyses.

Similarly to the observed in this study, Nutto et al. (2005) report the increase in available space for trees of A. angustifolia due to thinnings result larger crowns, and consequently, high diamenter growth. Curto et al. (2014) also recommend thinnings in plantations of $A$. angustifolia in order to favor the remaining trees.

Thinings 'from above' seem to be an appropriate management strategy for A. angustifolia. This approach requires a selection of potential individuals - dominant, good quality and well distributed in the stand - and after that, the definition of competitor individuals that should be removed to favor the first ones. Competitor individuals are also dominant and co-dominant ones that, in fact, compete for resources with potential trees.

Lower levels of competition can result

(i) from the mortality of neighboring trees;

(ii) from higher growth of object tree for analysis in detriment of the neighboring trees;

(iii) from the removal of competitors in population intervention (thinning 'from above').

To ensure the selected dominant trees can express all growth potential, competition has to be reducted or eliminated by removing competitor neighboring trees through planned and conscious interventions.

Nutto et al. (2005) claims that obtaining trees with $d b h$ of $\sim 40 \mathrm{~cm}$ is possible aiming a final density of, $\sim 150 \mathrm{ha}^{-1}$, in rotations of 30-40 years, depending on the site quality. In this study, an average $d b h$ of $40 \mathrm{~cm}$ for the 200 largest trees at 40 years seems to be only possible in sites of high productive capacity (IS 24), and even so, provided that they grown under favorable growth condition - dominant in relation to neighboring trees. However, it is once more highlighted that further interventions would have been necessary in the studied stands in order to control the competition among the individuals during the 20 years that succeeded thinning.

The space opened by thinnings is rapidly occupied by the crowns of remaining trees - the faster the lower the thinning intensity. This speed for occupying avilable space is also closely related to the site quality (NUTTO et al., 2005). This seems to be the reason for which it was not possible to detect diferences between the growth of dominant and dominated trees in lower quality sites. Possibly, in these sites, the intensity of thinnings was insufficient. In the more productive sites that support higher populational densities and competitions levels, there was significant benefit in the growth of all trees, mainly for those that already were dominant in relation to the stand average.

Some individuals, even exposed to a favorable condition of low competition, expressed by the dominance in relation to the neighboring trees, did not showed a higher growth in diameter. Other factors, such as soil depth or the presence of big-sized trees besides the eight adjacent neighboring ones can be probable causes for this inconsistency.

\section{CONCLUSIONS}

The results of the study allow the following conclusions:

- Multiple regression models were successfully fitted, showing that the site quality and competition level exerted by neighboring trees are important factors for the accumulated growth in diameter when all trees in a

FLORESTA, Curitiba, PR, v. 49, n. 4, p. 717 - 724, out/dez 2019.

Dobner Jr., M. et.al.

ISSN eletrônico 1982-4688 
population are analyzed. Once in dominance position (200 dominant trees ha $\left.{ }^{-1}\right)$, the site quality becomes the decisive factor for diameter growth.

- The importance of competition level for individuals before thinnings on the diameter growth show that trees of $A$. angustifolia submitted to long competition periods have a reduced capacity of diameter growth response, even if the competition is later reduced through thinnings.

- A. angustifolia is benefited for having a dominant position in relation to the neighboring trees, reaching diameters $50 \%$ larger at the end of production cycle when compared to the non-dominant ones. Thus, thinnings that favor selected trees by removing direct competitors - thinnings 'from above' - seems to be an appropriate management strategy for the species.

\section{ACKNOWLEDGEMENTS}

The authors are thankful to the private forest enterprise Florestal Gateados for supporting the study.

\section{REFERENCES}

ABRAF - Anuário Estatístico da Associação Brasileira de Florestas Plantadas 2010, ano base 2009. Brasília; 2010, 140 p.

CARVALHO, P. E. R. Espécies arbóreas brasileiras. Brasília, 2003, 1039 p.

CASTRO, R; SOARES, C; LEITE, H.; SOUZA, A.; MARTINS, F.; NOGUEIRA, G.; OLIVEIRA, M.; SILVA, F. Competição em nível de árvore individual em uma floresta estacional semidecidual. Silva Lusitanica, v. 22, n. 1, p. 43 - 66, 2014.

CUNHA, T. A.; FINGER, C. A. G. Competição assimétrica e o incremento diamétrico de árvores individuais de Cedrela odorata L. na Amazônia ocidental. Acta Amazonia, v. 43, n. 1, p. 9 - 18, 2013.

CURTO, R. D. A.; MATTOS, P. P.; BRAZ, E. M.; ZACHOW, R.; PÉLLICO NETTO, S. Caracterização da estrutura e desenvolvimento de modelos para quantificação do potencial madeireiro em povoamento não manejado de Araucaria angustifolia. Pesquisa Florestal Brasileira, v. 34, n. 80, p. 303 - 319, 2014.

FIGUEIREDO Fo, A.; KOHLER, S. V.; FELDE, J. L.; DIAS, N. A. Dinâmica do afilamento do tronco e da produção de madeira em plantios de Araucaria angustifolia. Cerne, v. 20, n. 4, p. 595 - 603, 2014.

FONSECA, C. R.; GANADE, G.; BALDISSERA, R.; BECKER, C. G.; BOELTER, C. R.; BRESCOVIT, A. D.; CAMPOS, L. M.; FLECK, T.; FONSECA, V. S.; HARTZ, S. M.; JONER, F.; KÄFFER, M. I.; LEAL-ZANCHET, A. M.; MARCElli, M. P.; MESQUITA, A. S.; PETRY, C. A. V.; PIOVESAN, F. N.; PUTZKE, J.; STRANZ, A.; VERGARA, M.; VIEIRA, E. M. Towards an ecologically-sustainable forestry in the Atlantic Forest. Biological Conservation, v. 142, n. 6, p. 1209 - 1219, 2009.

IBÁ - INDÚSTRIA BRASILEIRA DE ÁRVORES. Relatório anual. 2017. Disponível em: <http://iba.org/images/shared/Biblioteca/IBA_RelatorioAnual2017.pdf> Acesso em: 12 mar. 2018.

KOEHLER, A. B.; CORAIOLA, M.; PÉLLICO NETTO, S. Crescimento, tendências de distribuição das variáveis biométricas e relação hipsométrica em plantios jovens de Araucaria angustifolia (Bertol.) Ktze., em Tijucas do Sul, PR. Scientia Forestalis, v.38, n. 85, p. 53 - 62, 2010.

NUTTO, L.; SPATHELF, P.; ROGERS, R. Managing diameter growth and natural pruning of Parana pine, Araucaria angustifolia (Bert.) O Ktze., to produce high value timber. Annals of Forest Science, v. 62, p. 163 - 173, 2005.

PELTONIEMI, M.; MÄKIPÄÄ, R. Quantifying distance-independent tree competition for predicting Norway spruce mortality in unmanaged forests. Forest Ecology and Management, v. 261, p. 30 - 42, 2011.

R CORE TEAM. R: A language and environment for statistical computing. R Foundation for Statistical Computing, Vienna, Austria. URL https://www.R-project.org/. 2016.

SANTOS, W. C.; ROSOT, N. C.; ROSOT, M. A. D. Características edáficas relacionadas à produção de um povoamento de Araucaria angustifolia (Bert.) O. Kuntze. Floresta, v. 40, n. 1, p. 37 - 48, 2010.

SCHNEIDER, P. R.; FINGER, C. A. G.; HOPPE, J. M. Produção da Araucaria angustifolia (Bert.) O. Ktze. na região do Planalto Médio do Estado do Rio Grande do Sul. Ciência Florestal, v. 2, n. 1, p. 99 - 118, 1992.

SEITZ, R. A. Erste Hinweise für die waldbauliche Behandlung von Araukarienwäldern. Annales des Sciences Forestiéres, v.43, p. 327 - 338, 1986.

THOMAS, P. Araucaria angustifolia. The IUCN Red List of Threatened Species 2013. 2013. Disponível em: <http://www.iucnredlist.org/details/32975/0> Acesso em: 12 mar. 2018. 